\title{
An Afrocentric critique of sub-state actors in South Africa's foreign policy: Case of Limpopo province
}

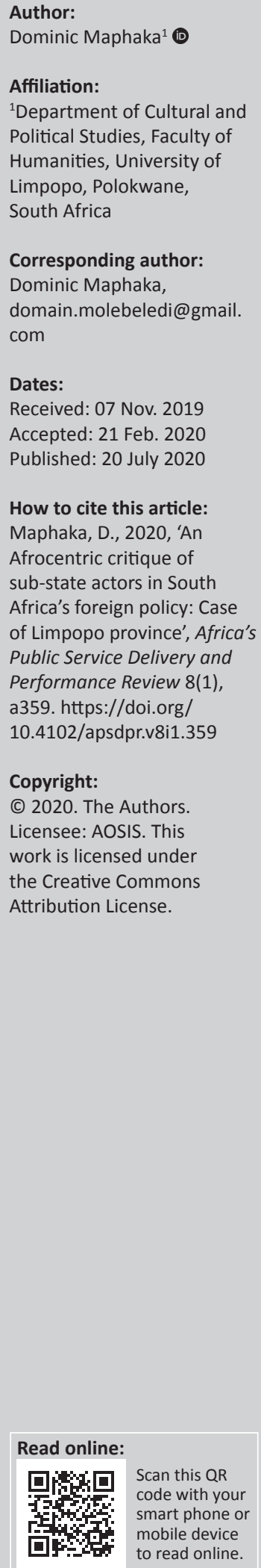

Background: Foreign Policy-Making and implementation have traditionally been the domain of the central government.

Aim: This article uses Limpopo province as a test case to critique the role of Sub-state actors in South Africa's foreign policy processes from an Afrocentric perspective. The main argument of this desktop article is that sub-state actors and non-state actors collaborate with central government, the main actor to make and effectively implement foreign policy.

Setting: It locates the involvement of the provinces in international relations by reference to the African experience prior to the arrival of colonisers.

Methods: This article employs Afrocentric qualitative research methodology as articulated by Asante (2007), Mazama (2001), Ntseane (2011) and Schreiber (2000) to provide a complete analysis and understanding of sub-state actor's involvement in South Africa's foreign policy, by using Limpopo province as a test case study.

Results: Limpopo province attracts trade and investment by marketing itself abroad. The province draws skills needed for human resource development by sending officials and students to institutions of higher learning abroad. Even though the province involvement in international relations is not without challenges. Included here are the MOUs that are stalling because of a lack of implementation strategy and skilled personnel, for example, those signed with its counterparts of Sweden, Italy and Cuba. Public participation in the FPM process is very limited because of a number of reasons.

Conclusion: This article recommends that the central government should deepen training, dialogue and exchange of ideas between national and provincial officials. In line with conditional grants that they receive, provinces should seek additional funds from the central government to improve, develop and deepen their engagement in international relations. Regular platforms accessible to public members should be established across the province.

Keywords: Afrocentricity; actors; foreign policy; Limpopo province; South Africa.

\section{Introduction}

South Africa's democratic dispensation spurred many changes, especially the expansion of provinces from four to nine. The newly adopted Constitution grants provinces autonomy on executive and legislative matters within their jurisdiction, including their indirect involvement in foreign affairs. The provinces are exploiting their relative autonomy on legislative and executive matters to engage in international relations. The involvement of South African provinces in international relations is not a new phenomenon; the Kingdom of Mapungubwe, origin of the contemporary Limpopo province, traded with other nations prior to colonisation. Previous studies overlooked the African experiences that could provide valid knowledge about the involvement of the South African sub-state actors in foreign affairs. As a result, they lump the experience of European provinces' engagement in foreign affairs with their South African counterparts. Whilst the South African state did not exist by then, international relations were mainly conducted by independent regions which laid a basis for state and sub-state actors. This article employs Afrocentric qualitative research methodology as articulated by Asante (2007), Mazama (2001), Ntseane (2011) and Schreiber (2000) to provide a complete analysis and understanding of sub-state actor's involvement in South Africa's foreign policy, by using Limpopo province as a test case study. It locates the involvement of the provinces in international relations by reference to the African experience prior to the arrival of colonisers. Moreover, this article expounds on how Limpopo province engages in foreign policy-making (FPM) and implementation by providing provincial actors that engage in international relations. It 
demonstrates opportunities and challenges faced by the province in the international arena and presents the possible remedies.

\section{Literature review \\ Sub-national governments}

The existing literature traces the South African provinces' involvement in the FPM process and international relations to the outset of democratic dispensation in 1994. This should be understood in the context that the government under rule was highly centralised and provinces were not featured as players in international relations. Geldenhuys (1998) corroborates this, when he says that:

Given their modest powers and the centralist thrust of the state, it is not surprising that South Africa's provinces never featured as players in the international arena. Studies of South African foreign policy in the era of white rule accordingly did not pay attention to the provinces as international actors. (p. 4)

Historical developments such as the interim Constitution of 1993 and the 1996 Constitution laid a foundation for provincial engagement in foreign affairs (Randt 2011; Department of Justice 1993). Matshili (2013) and Nganje (2013) assert that political parties represented at the Constitutional Assembly in 1994 had a polarising view on how democratic South Africa should look like. Some parties preferred federalism, whilst the African National Congress (ANC) was calling for the unitary system. The negotiations yielded a government that could be described as quasifederalism or decentralised unitary system, with nine provinces (Geldenhuys 1998). The new Constitution possesses the aspects of unitary government whilst giving some degree of autonomy to sub-national governments (Randt 2011). For example, it grants provinces relative autonomy on legislative and executive matters within their jurisdiction (Stander et al. 2014).

But there is no constitutional provision that grants subnational government authority to engage directly in international relations (Nganje 2013). Pursuant to the South African Constitution, the engagement in international relations, particularly the signing of agreements, is the domain of the central government. In Chapter 14, Section 231 (1) of the Constitution stipulates that the negotiating and signing of all international agreements is the responsibility of national executive' (The Constitution of the Republic of South Africa 1996). But such agreements must be approved by the two national Legislative Houses before they bind the Republic (Hudson 2010). Section 231 (2) proclaims that the international agreements must be approved by both the National Assembly and the National Council of Provinces (NCOP) to bind the country. In this regard, the ratification or accession must be voted by six provincial legislators. The technical and administrative and those agreements that do not necessitate ratification or accession signed by the national government are not falling within this scope. But they must be presented before the two Legislative Chambers within a reasonable time (Nganje 2016; The Constitution of the Republic of South Africa 1996).

White (1996) and Nganje (2015) underscore that provincial delegations submit their inputs on foreign policy to the central government through the national forum for public consideration of issues affecting the provinces. The latter is a platform afforded to NCOP to represent the interests of provinces (Randt 2011). Provincial delegations make and execute legislation and policies on socio-economic matters. Many of such areas necessitate engagement with their counterparts abroad; hence, provinces become involved in international relations (Nganje 2015). Geldenhuys (1998) echoes the same sentiment; the central government cannot fulfil the development needs of provinces alone. As a result, the province seeks resources to fuel development from abroad. From 1994 to date, sub-national governments are engaging in international relations to promote economic growth and development within their jurisdictions. For example, they form cooperation ties to attract trade, investment and official development assistance (ODA), including exchanging ideas on governance with their international counterparts (Nganje 2016; Zondi 2012).

In agreement, Zondi (2012) states that development partnership is targeted by South African provinces that are facing poverty to attract skills and resources needed for development from their counterparts. Hence, most subnational governments target European Union member states and countries of the East. For the ruling party (ANC) and national executive, the involvement of sub-national governments in international relations is a complementary initiative. They cooperate with the central government to localise foreign policy (Nganje 2016). White (1996), Geldenhuys (1998) and Nganje (2015) submit that the Department of International Relations and Cooperation (DIRCO) urges provinces to sign non-binding agreements or cooperation and memorandum of understanding (MOU) with their international counterparts. To provinces, intergovernmental relations in foreign affairs enable them to benefit from South Africa's partnership with other states. The provincial agencies on trade and investment matters collaborate with the national Department of Trade and Industry (DTI) and South African embassies deployed abroad. In this regard, DTI fund and aid the provincial government agencies tasked to attract trade and investment. The South African embassies and consulates are marketing the provinces abroad. For example, by connecting them to trade and investment opportunities abroad. Provincial legislators through the Select Committee on Trade and International Relations (SCTIR) assess and scrutinise international agreements signed by the central government (Nganje 2013, 2015).

South African provinces fuse their engagement in foreign affairs with Tshwane's foreign policy and national development objectives (Geldenhuys 1998; Hudson 2010). To actualise this, DIRCO encourages provinces to form an 
International Relations Unit (IRU). The unit is tasked to coordinate the activities of national and provincial departments and local governments abroad (Nganje 2015). The Intergovernmental Relations and Provincial Protocol (A Directorate for Provincial Liaison) based at DIRCO was established in 2009 to facilitate liaison between the two spheres of government in foreign affairs. In other words, the Directorate seeks to facilitate the common implementation of foreign policy (Geldenhuys 1998; Nganje 2015). The Consultative Forum on International Relations (CFIR) was established in 2008, to facilitate coordination, exchanges and accountability by managing intergovernmental relations in foreign affairs. The Forum is the intergovernmental structure composed of senior officials from spheres of government and other relevant stakeholders. It meets frequently to receive reports from non-central governments about their activities abroad. The committee of Ministers and Members of Executive Councils (MinMECS) facilitates collaboration between national ministers and their provincial counterparts (DIRCO 2011; Nganje 2015; Zondi 2012).

Apart from that, a number of workshops were held whereby delegations from national departments deliberated with and trained their sub-national government's counterparts on matters of foreign affairs. Provincial International Relations Coordinating Group (PIRCG) was established to support the extraordinary sessions. This short-lived forum was established to provide regular training to local and provincial officials on matters of foreign affairs (Nganje 2015). In agreement, Cornago (2010) asserts that South Africa is amongst those countries that collaborate with sub-state actors to promote national development and democratisation of the policy-making process. Amongst other things, provinces are establishing ties with their counterparts from neighbouring countries. Regional integration championed by the Southern African Development Community (SADC) is laying a basis for engagement between South African provinces and their counterparts in the region. The 1996 Foreign Policy Discussion Document asserts that South Africa should prioritise partnerships with its regional counterparts and promote regional development through inter-trade by her provinces with their regional counterparts (White 1996).

Equally to other countries, Tshwane's foreign policy has spill-over effects. The international agreements signed by the national government with its foreign counterparts often pertain to matters within the jurisdiction of provinces. For example, seven of the South African provinces are bordering with nation states. For this reason, they cooperate with the national government to combat cross-border crime such as poaching, illegal migration and smuggling of goods. In other words, provinces partake in the implementation of such agreements. Apart from that, their common development needs with neighbouring countries encourage them to establish mutual ties (Geldenhuys 1998; White 1996). The South African provinces are also holding international events and attending world trade fairs. They collaborate with the national International Marketing Council (IMC) that promotes the South African image (Zondi 2012). It is worthy to note that provinces do not have representatives stationed abroad. They interact with their foreign counterparts through occasional visits (Geldenhuys 1998). The central government through DIRCO and South African diplomats stationed abroad set appointments on behalf of provinces (Zondi 2012).

Zondi (2012) and Nganje (2016) raise concerns about the outright alignment of provincial involvement in international relations with the national foreign policy framework. They reference the relative autonomy the Constitution grants to provinces as a justification for provincial governments to develop a different strategy to international relations. But, foreign policy is the extension of national interests and values of the country abroad. This means that subnational and national governments should take collective responsibility to implement national interests and values without diverging from the fundamental foreign policy framework. Apart from that, Africans value collectivism rather than Eurocentric individualism (Ntseane 2011). The provincial deviation from the country's foreign policy framework will cause contradiction and confuse South Africa's partners abroad. On cooperative government and intergovernmental relations, Chapter 3 of the South African Constitution emphasises interdependence and interrelations amongst spheres of government. Section 41 (1) (g) of this chapter proclaims that spheres of government must carry out their duties without undermining the work and integrity of others (The Constitution of the Republic of South Africa 1996). The adoption of a different approach to international relations could be exploited by the provincial government led by minority and ethnic leaders to undermine national unity. Thus, such developments could revive ethnic and racial divisions of the past perpetrated by the apartheid Bantustan system.

\section{Non-state actors}

Pursuant to the 2011 White Paper on South Africa's Foreign Policy, protection and promotion of national interest are not the domain of the central government only. There should be deliberations and exchange of ideas with other stakeholders on FPM and implementation. In this regard, DIRCO takes into account the inputs of ordinary people and other stakeholders in matters of foreign affairs (DIRCO 2011). The non-state actors participate directly or indirectly in the FPM and implementation process. Included in this category are individuals, the business community, non-governmental organisations (NGOs), research institutions and media (Hadebe 2015; Masters 2012; Spies 2010). Bohler-Muller (2012) observes that South Africa's foreign policy is guided by the philosophy of 'Ubuntu', which stresses the interconnectedness and interdependence between the central government and nationals. As part of ensuring collective responsibility, the government is giving the public a platform to participate in the FPM process. It seeks to facilitate transparency by allowing community participation so that 
the public can hold embassies and other actors in foreign affairs accountable. In other words, international relations are a collective consent rather than being confined to state-state engagement.

Department of International Relations and Cooperation's annual meeting in 2009 put more emphasis on the democratisation of the FPM process. The theme 'Closing the gap between domestic and foreign policies' attests to government recognition of other actors' input in foreign affairs (Hudson 2010). Though not operating effectively, the South African Council on International Relations (SACOIR) was established by DIRCO in 2009 to facilitate the participation of the public and other stakeholders in foreign policy. When operating effectively, the Council will serve as a platform whereby members of the public could submit their inputs on matters of foreign affairs to experts and DIRCO officials (Bohler-Muller 2012; DIRCO 2011). Department of International Relations and Cooperation is holding debates at universities. The former Minister of International Relations and Cooperation (Maite Nkoana-Mashabane) was visiting universities to grant students and other stakeholders an opportunity to submit their inputs (Masters 2012; White 1996). These events suggest that public participation is very limited, a phenomenon that could be described as disconnecting communities from their experiences and denying them an opportunity to shape their development. This is corroborated by the absence of a regular accessible platform at the provincial level for members of the public to submit their inputs in the FPM process. In other words, ordinary people on the grassroots are placed at the margins of their experiences. Drawing from Afrocentricity, provincial inhabitants are placed at the margins of policy-making as was the case during colonialism and apartheid.

Another referential case of non-state actor's participation is the legal action taken by the Treatment Action Campaign (TAC) against Pfizer's name-brand medications over high prices of antiretroviral medicines (ARM). A good example is the legal action taken by this civil rights movement which drew attention from the international community and compelled the government to render ARM to human immunodeficiency virus (HIV) and acquired immunodeficiency syndrome (AIDS) patients. For example, they challenged the patent rights which inhibit citizens' access to ARM. Consequently, companies manufacturing ARM allowed franchising (Hudson 2010). Equally the impact was made by interest groups such as the Congress for South African Trade Unions (COSATU) over Chinese textile imports to South Africa. After its deliberations with COSATU, the government signed an MOU with China to impose quotas on the latter textile imports (Graham 2013; Hudson 2010). The research institutions such as the South African Institute for International Affairs (SAIIA), Institute for Security Studies (ISS) and the Institute for Global Dialogue (IGD) issue publications on South Africa's foreign policy. The printing media or broadcasting companies such as the Sunday Times, Mail $\mathcal{E}$ Guardian, City Press and digital media like e-News
Channel broadcast about South African engagements in international relations (Hadebe 2015; Siko 2014).

Masters (2012) states that following the renaming of the Department of Foreign Affairs in 2009, its successor collaborated with civil society groups to write the 2011 White Paper on Foreign Policy. The Paper was approved by the cabinet and National Assembly in 2011. Likewise, its predecessor collaborated with civil society in writing the 1998 White Paper on Peace Missions, which laid a foundation for their involvement in peace-making abroad (Department of Foreign Affairs 1998). The 2011 White Paper asserts that South African non-state actors collaborate with the central government in promoting international peace (Cilliers 1999). Spies (2010) underscores that research institutions are involved in implementing South Africa's principle of promoting peace, stability and security. A referential case is the involvement of the ISS in the continental disarmament. Examples include the mediation role undertaken by the Centre for Conflict Resolution (CCR) in Burundi during the 1990s. The conflict management was undertaken by the African Centre for the Constructive Resolution of Disputes (ACCORD) in Congo and Sudan, respectively. The IGD partook in the democratic transition in Nigeria and deliberated with Lesotho civil society groups following the South African military intervention in 1998.

Makokera (2015) observes that South Africa's economic diplomacy is not confined to the central government and sub-national governments. The 2011 White Paper issued by the DIRCO stresses that effective economic diplomacy needs collaboration between government, the business community and labour. This explains the involvement of the business community in South Africa's foreign policy. The business community was exchanging ideas on investment with national executives during Mbeki administration. Zondi et al. (2014) indicate that during Mbeki incumbency, Big Business Working Group (BBWG) was established as a forum to facilitate consultations and exchanges between the central government and the private enterprises. On the other hand, Zuma had a large business entourage on his international visits, particularly those pertaining to BRICS (Brazil, Russia, India, China and South Africa) bloc. During his incumbency, the DIRCO held a meeting with the business community on African Agenda 2063. The investments of South African companies in the region strengthen its relations with SADC member states. Most South African companies invested largely in extractive, manufacturing and service sector in the region (Masters 2012; Spies 2010). Hadebe (2015) remarked that under the auspices of DTI, private enterprises such as Mobile Telecommunication Network (MTN) and Shoprite strengthen South Africa's ties with other nations. Amongst other non-state actors that partake in foreign policy is the ruling party, the ANC through the Sub-Committee on International Relations (Hughes 2004). Through its National conference, the ANC is the main actor in the FPM process. The employment of party-to-party bilateral relations as opposed to diplomacy in the Southern African 
region necessitates a strong organisational committee (Hadebe 2015).

As stated earlier, the literature traces the engagement of South African provinces in international relations to the outset of democracy, although the Kingdom of Mapungubwe, origin of the contemporary Limpopo Province, traded with nation-states abroad prior to colonisation. The studies conducted by Nyathi (2005) and Chirikure (2014) indicate that Mapungubwe traded with the East and Islamic countries through the Indian Ocean. The Islamic traders (i.e. Saudi Arabia and Persia) were exchanging their beads, ceramics and cloth for ivory, hides, ostrich feathers and gold. Development of the then Southern Africa cannot be described without crediting Southern Arabia, Persia, India and China. East African coast was used as the trade passage for goods and products destined to Southern Africa and its trade partners. Antonites, Uys and Antonites (2016) concur that Mapungubwe was the Southern African market hub, trading with Central Africa, Europe, the Middle East and Asia.

\section{Limpopo province}

The province involvement in international relations follows the patterns of South Africa's foreign policy. Zondi et al. (2014) submit that the African continent, especially the SADC region, takes precedence in Tshwane's foreign policy. In other words, the country's development needs cannot be separated from those of its counterparts on the continent. Equally, the developing countries are prioritised in South Africa's foreign policy as projected by the principle of South-South cooperation. The last category of South African priorities is developed countries and participation in multilateral institutions. In keeping with the central government commitment to promoting continental growth and development through regional integration, Limpopo province prioritises the SADC region in its international relations. Masters (2014) agrees that Limpopo is amongst other provinces implementing the country's continental development objectives through its development assistance division stationed within its IRU.

Limpopo province is a gateway to Southern Africa. For example, the Musina Special Economic Zones (SEZ) is sited near the South African and Zimbabwe border. It is incorporated in the Trans-Limpopo Spatial Development Initiative (SDI). The latter is envisaged as facilitating regional intra-trade and development through the transfer of skills. The fact that this SEZ is adjacent to trade routes to SADC and other regions on the continent coupled with incentives such as developed infrastructure and minerals attracts investment (DTI 2018). Geldenhuys (1998), Zondi et al. (2014) and Matshili (2013) indicate that the province has signed the nonbinding cooperation agreement and MOU with its Mozambique counterpart, Gaza province. The agreement includes trade, people-to-people relations, education and cultural exchanges. The province exploits regional initiatives such as the Maputo Development Corridor, Lesotho Highlands Water Project and the Great Limpopo Transfrontier Park to facilitate development in its jurisdiction. The province has signed MOU with Beitbridge, Gwanda, Umzingwane and the City of Bulawayo of Matebeleland region (province) in 2000. The said MOU resulted in the establishment of the Trans-Limpopo SDI. A number of institutions and implementation mechanisms were established to make the signed agreements effective. Amongst other established institutions is the SDI tasked to facilitate the implementation of policies. The coordination Committees were established, namely A Joint Executive Committee (JEC) and a Joint Technical Working Committee (JTWC) to coordinate the implementation of programmes and MOU (Matshili 2013).

\section{Provincial actors in foreign policy- making and implementation The premier and other officials}

As stated earlier, provinces partake in FPM through the NCOP. Limpopo province is involved in international relations through the premier and other officials. As the provincial head of the executive, the premier markets the province abroad and enters into new partnerships. He also assesses and deepens the existing ones. The premier approves the visits undertaken by Members of the Executive Council (MECs), Director Generals and other officials of provincial departments (Matshili 2013). The then Premier Ngoako Ramatlhodi had undertaken a number of official visits to SADC member states, namely, Botswana and Mozambique (Gaza province). The visit he undertook in 1998 was meant to deliberate on areas of mutual interests such as cross-border crime. Maputo port is the more preferable trade route to Limpopo province than its distant counterparts. The provincial rail and automotive roads are connected to Maputo port and are also closed to the province extractive and agricultural sector. Its proximity to the province cuts trade costs (Zondi 2012). It is also recorded that the former President of Botswana Ketumile Masire visited the province in April 1996. Apart from continental visits, the former Premier (Ramatlhodi) travelled to Taiwan (Republic of China), China (Peoples Republic of China), Britain, Austria and Germany to attract trade, ODA and investment (Geldenhuys 1998).

His successor, Sello Moloto, made a state visit to Gaza in 2007. The Gaza Governor visited the province in 2007 to attend a JTWC session. During the visit by Gaza Governor, the two provinces signed a work plan, which serves as a framework for the implementation of MOU. Limpopo provincial government executed the country's commitment to continental development by donating two computers to Gaza province (Matshili 2013). Apart from international visits undertaken by premiers, provincial Minister of Finance, Trade, Tourism and Industry graced investment summit in Zimbabwe. They also paid a number of visits to Mozambique. Other delegates dispatched to Zimbabwe and Botswana for academic purposes 
and returned to Harare for commercial issues (Geldenhuys 1998). Other provincial MECs and senior officials paid a visit to Europe, Asia and African countries such as Namibia, Zambia, Kenya and Ghana. The province had also received the Netherlands Minister of Education (Geldenhuys 1998).

\section{International Relations Unit}

The IRU was established to coordinate intergovernmental relations abroad. It collaborates with DIRCO to coordinate and facilitate the visits of officials and provincial international relations programmes abroad. This is meant to avoid replication on policy implementation. For example, it provides advice to officials participating in international relations. Included here is the coordination of incoming and external visits through the arrangement of diplomatic visas and passports. The two institutions provide advice to the province on implications pertaining to the signing of MOUs. The IRU keeps and updates the information on international visits undertaken by provincial officials. It also teaches provincial officials about diplomatic etiquette. It sets and coordinates regular sessions of the provincial International Relations Committee (IRC) (Matshili 2013).

\section{Opportunities and challenges}

The development needs of the province cannot be fulfilled by its collaboration with the central government alone. For this reason, the province is attracting ODA needed for socioeconomic growth, development and job creation by engaging in international relations. It attracts trade and investment by marketing itself abroad. The province draws skills needed for human resource development by sending officials and students to institutions of higher learning abroad. Even though the province involvement in international relations is not without challenges. Included here are the MOUs that are stalling because of a lack of implementation strategy and skilled personnel, for example, those signed with its counterparts of Sweden, Italy and Cuba. Public participation in the FPM process is very limited because of a number of reasons. Firstly, the SACOIR, which was established to maximise its participation, is not operating effectively. Despite the provincial governments being regarded as the sphere closed to voters, there is no regular provincial platform accessible for public participation in the FPM process. The participation of individuals is limited to public dialogue presided over by Minister of International Relations and Cooperation held occasionally at universities. Thus, provincial inhabitants are placed at the margins of the policy-making process as was the case during colonialism and apartheid. There is a lack of resources needed to conduct international relations such as skilled personnel and finance (Matshili 2013).

\section{Conclusion and recommendations}

This article relocates the involvement of Limpopo province in international relations to a period before colonisation. The Kingdom of Mapungubwe traded with the countries of Asia and the Middle East. After democratic dispensation, the former four provinces (Natal, Orange Free State, Transvaal and Cape) were transformed and increased to 9. The 1996 Constitution grants provinces relative autonomy on legislative and executive matters. Subnational governments (provinces) participate in the FPM process through NCOP, which represents the interests of provincial inhabitants. Whilst the Constitution preserves the negotiation and the signing of agreements to the central government, accession or ratification of such compact must be approved by NCOP before they could bind the Republic. The provinces are engaging in international relations through signing nonbinding cooperation agreements and MOUs with their counterparts abroad. Institutions and committees were established to facilitate coordination, management and effective implementation of their engagement in international relations, namely, CFIR, IRU and MinMECS. Apart from substate actors, non-state actors such as individuals, NGOs, business communities and research institutions involved in the FPM process. Amongst other sub-state actors, Limpopo province involved in international relations by following the central government's foreign policy patterns. This should be understood in the context that Africans value collective responsibility rather than Eurocentric individualism. In this regard, the African continent, especially the SADC region, takes precedence to the province. There are challenges faced by the province in international relations. Firstly, some MOUs are stalling because of the lack of skilled personnel and finance. Secondly, public participation is very limited because there is no accessible provincial platform that could facilitate their participation. This article recommends that the central government should deepen training, dialogue and exchange of ideas between national and provincial officials. In line with conditional grants that they receive, provinces should seek additional funds from the central government to improve, develop and deepen their engagement in international relations. Regular platforms accessible to public members should be established across the province. Though this article is not without limitations, the data were drawn from secondary sources only. The literature on Limpopo province involvement in international relations is very limited, because few studies were conducted in this area.

\section{Acknowledgements}

The author would like to thank Mr Matome Vincent Hanyani for reviewing this article.

\section{Competing interests}

The author declares that no competing interests exist.

\section{Author's contributions}

I declare that I am the sole author of this research work.

\section{Funding information}

This research received no specific grant from any funding agency in the public, commercial or not-for-profit sectors. 


\section{Ethical consideration}

This article followed all ethical standards for carrying out a research without direct contact with human or animal subjects.

\section{Data availability statement}

Data sharing is not applicable to this article as no new data were created or analysed in this study.

\section{Disclaimer}

The views and opinions expressed in this article are those of the author and do not necessarily reflect the official policy or position of any affiliated agency of the author.

\section{References}

Antonites, A.R., Uys, S. \& Antonites, A., 2016, 'Faunal remains from MNR74, a Mapungubwe period settlement in the Limpopo Valley', Annals of the Ditsong National Museum of Natural History 6(7), 26-38.

Asante, M.K., 2007, An Afrocentric manifesto: Toward an African renaissance, Polity Press, Cambridge.

Bohler-Muller, N., 2012, Nuanced balancing act: South Africa's national and international interests and its 'African agenda', South African Institute of International Affairs, Johannesburg.

Chirikure, S., 2014, 'Land and sea links: 1500 years of connectivity between Southern Africa and the Indian Ocean rim regions, AD 700 to 1700 ', The African Archaeological Review 31(4), 705-724. https://doi.org/10.1007/s10437-014-9171-6

Cilliers, J., 1999, An emerging South African foreign policy identity?, Institute for Security Studies, Pretoria.

Constitutional Assembly, 1996, The Constitution of the Republic of South Africa, Department of Justice and Constitutional Development, Pretoria.

Cornago, N., 2010, 'On the normalization of sub-state diplomacy', The Hague Journa of Diplomacy 5(1), 11-36. https://doi.org/10.1163/187119110790930869

Department of Foreign Affairs, 1998, White Paper on South African participation in international peace missions, viewed 15 January 2020, from https://www.gov.za.

Department of Justice, 1993, Constitution of the Republic of South Africa, viewed 15 January 2020, from https://www.justice.gov.za.

Department of International Relations and Cooperation (DIRCO), 2011, Building a better world: The diplomacy of Ubuntu: White Paper on South Africa's foreign policy, Department of International Relations and Cooperation, Pretoria.

Department of Trade and Industry (DTI), 2018, South African special economic and industrial development zones, The Department of Trade and Industry, Pretoria.

Geldenhuys, D., 1998, The foreign relations of South Africa's provinces, South African Institute of International Affairs, Johannesburg.

Graham, C.J., 2013, 'The role of national trade union organisations in South Africa's foreign policy processes: 1999-2012', Master's dissertation, Stellenbosch University, viewed 06 November 2019, from https://scholar.sun.ac.za.
Hadebe, S., 2015, 'South Africa's post-apartheid foreign policy towards Southern Africa, 1994-2014: Partner or hegemon?', PhD thesis, University of KwaZulu-Natal, viewed 11 September 2019, from https://researchspace.ukzn.ac.za.

Hudson, H., 2010, 'Continuity and change: An evaluation of the democracy-foreign policy nexus in post-apartheid South Africa', Journal for Contemporary History 35(2), 108-130.

Hughes, T., 2004, Composers, conductors and players: Harmony and discord in South African foreign policy making, Konrad-Adenauer-Stiftung, Johannesburg.

Makokera, C.G., 2015, South African economic diplomacy: Engaging the private sector and parastatals, Institute for Security Studies, Pretoria.

Masters, L., 2012, 'Opening the "black box" South African foreign policy-making', in C. Landsberg \& J. Van Wyk (eds.), South African foreign policy review, pp. 20-41, Africa Institute of South Africa and Institute for Global Dialogue, Pretoria.

Masters, L., 2014, 'Building bridges? South African foreign policy and trilateral development cooperation', South African Journal of International Affairs 21(2), 177-191. https://doi.org/10.1080/10220461.2014.942206

Matshili, V.E., 2013, 'Sub-national governments and foreign policy: The case of the Limpopo province in South Africa', Master's dissertation, University of South Africa, viewed 07 November 2019, from https://www.semanticscholar.org.

Mazama, A., 2001, The Afrocentric paradigm contours and definitions', Journal of Black Studies 31(4), 387-405. https://doi.org/10.1177/002193470103100401

Nganje, F., 2013, 'Paradiplomacy: A comparative analysis of the international relations of South Africa's Gauteng, North West and Western Cape provinces', PhD thesis, University of Johannesburg, viewed 07 November 2019, from https://ujcontent. uj.ac.za.

Nganje, F., 2015, 'Intergovernmental relations on foreign Affairs in South Africa: A twenty-year review', Strategic Review for Southern Africa 37(2), 52-73.

Nganje, F., 2016, 'Historical institutionalism and the development of sub-state diplomacy in South Africa', Journal for Contemporary History 41(1), 149-168. https://doi.org/10.18820/24150509/jch.v41i1.8

Ntseane, P.G., 2011, 'Culturally sensitive transformational learning: Incorporating the Afrocentric paradigm and African feminism', Adult Education Quarterly 61(4), 307-323. https://doi.org/10.1177/0741713610389781

Nyathi, P., 2005, Zimbabwe's cultural heritage, 'amaBooks, Bulawayo.

Randt, M.D., 2011, 'The representation and participation of provinces in international relations in South Africa, case study: Western Cape Province', Master's dissertation, Stellenbosch University, viewed 07 November 2019, from https:// scholar.sun.ac.za.

Schreiber, L., 2000, 'Overcoming methodological elitism: Afrocentrism as a prototypical paradigm for intercultural research', International Journal of Intercultural Relations 24(5), 651-671. https://doi.org/10.1016/S0147-1767(00)00021-3

Siko, J.A., 2014, "'Democratic" foreign policy making and the Thabo Mbeki', PhD thesis, University of South Africa, viewed 07 November 2019, from https://uir.unisa.ac.za.

Spies, Y., 2010, 'South Africa's foreign policy: 2010 overview', South African Yearbook of International Law 35(1), 278-303.

Stander, A., Monyae, M., Ngese, M., Boshane, T. \& Baynes, I., 2014, International relations and protocol. Induction handbook for members of parliament and provincial legislatures, South African Legislative Sector, Pretoria.

White, G., 1996, 'Grassroots foreign policy? A case for provincial participation', Policy Research Unit Office of the Premier 13(4), 25-29.

Zondi, S., 2012, 'The international relations of South African provinces and municipalities: An appraisal of federated diplomacy', in C. Landsberg \& J. Van Wyk (eds.), South African foreign policy review, pp. 42-67, Africa Institute of South Africa and Institute for Global Dialogue, Pretoria.

Zondi, S., Masters, L., Jumat, W., Reinecke, R. \& Boldt, R., 2014, A foreign policy handbook: An overview of South Africa's foreign policy in context, Institute for Global Dialogue and UNISA, Pretoria. 